\title{
RAIN-MAKING IN EQUATORIAL AFRICA
}

Ir was after a long hot march that I one day in May Igo4 found myself enjoying the shade of a beautiful sycomore tree not far from the village of LEDJU, the hereditary Chief Rainmaker of the Bari tribe, situated on the summit of a small hill known locally as Sindiro, some 25 miles S.S.E. of Gondokoro, on the Equatorial Nile. LEDJU (an intelligent man of about 40 years of age, differing in appearance from the average Bari by allowing his hair to grow to a length of about nine inches instead of following the usual tribal custom of periodically shaving the head) and I had met before, though not at this particular spot, and had previously discussed the rainmakers' magical art. The Chief had promised, as a special favour, to introduce me to his three assistant rainmakers (WANI, PETIA and Lako, intelligent men of about thirty years of age with long hair like their Chief LEDJU), with their magical implements and to demonstrate to me the mysteries of rainmaking. I accordingly reminded the Chief of his promise, whereupon I was conducted to his village which consisted of a collection of some 15 huts, circular in shape, about 15 feet in diameter, with mud walls 3 feet high, and tall conical grass roofs, the whole surrounded by a circular fence or wall composed of stout stakes of very hard wood some 7 feet high and about 5 feet apart, interwoven with a thick wall of thorn, overgrown with wild creepers and climbing pumpkin plants, presenting a formidable barrier to leopards and hyenas, especially the latter, which abound in the neighbourhood. A space about 3 foet wide and 4 feet high had been left in this thorn wall to serve as an entrance to the village. Through this we entered, stooping considerably, in order to avoid the mass of thorns and creepers which 
formed an arch over the entrance. On entering we proceeded to the back of a hut situated to the left of the gateway. Here, between the hut and the village wall described above, was a miniature enclosure about to feet in diameter with a wall similar in construction and shape to the outer one. This enclosure contained most of the strange implements used by the rainmakers. Arranged on the ground within the enclosure were some 20 slabs of gneiss of an average size of 16 inches by 12 inches and about 5 inches thick and hollowed in the centre, in actual appearance very similar to the stones used in the grinding of corn by many of the Negro tribes inhabiting the Equatorial Nile Basin. Each hollow or nest contained from two to eight pieces of rock crystal and granite, the latter, in two colours, pink and green, and both circular and conical in shape. A number of small earthen pots, capable of holding about I pint, were filled with water and placed near the "nests." Laid across these hollowed stones or nests, were numerous iron rods varying in size and shape. The Chief now explained to me : when rain is required by, say, the inhabitants of a neighbouring village, a deputation generally consisting of the village headman and some two or three elders waits upon the rainmaker at his own village and begs him to give them rain for their crops. The request is accompanied with a present or fee in the form of chickens, sheep or goats according to the means of the parties requiring rain. One or more of these animals are forthwith killed and eaten by the party, the rainmakers consuming the larger share. The feast over, the three assistant rainmakers proceed to the enclosure and first remove the iron rods placing them in a perpendicular position by leaning them against a thin line made from the bark of a tree and stretched more or less taut across the enclosure and tied to the stakes in the thorn wall of the small enclosure. They then wash the stones and crystals with water from the small earthenware pots and replace them in their respective nests.

Each assistant has his own special set of nests which are under his individual care and are known to him by various names (names of former rainmakers or members of their 
families). On the completion of this ceremony by the assistants, the Chief Rainmaker appears upon the scene with a small pot of fat or vegetable oil, extracted from the semsem seed or ground nut.

The Chief, having first placed himself in a squatting posture near the nests, pours a little of the oil into the palm of his left hand, then placing the oil pot on the ground before him, rubs his hands together, then takes up the stones one by one from their nests, rubs them with the oil on his hands, at the same time chanting or mumbling to himself words to the following effect:-

I am the Son of LUGAR, my home is near the mighty river Nile. Sновi has brought me a fine fat fowl, we have had a very good feast. Shobi wants rain for his crops; if he does not get rain all his crops will fail and he and all his women will either die of hunger or migrate to some distant land and become the slaves of strangers. $\mathrm{Oh}$, the rain must come! Oh my father, Send the rain! Send the rain! Send the rain !! You were in your day a mighty rainmaker; many people believed in your power, brought you many goats and sheep and you became rich.

Your flocks were as numerous as the grass which now covers the surface of these lands. Now you are dead; and I am left to make rain in your stead!

Oh Send the rain I Send the rain!

In conjunction with the stone oiling ceremony, the numerous iron rods are also brought into requisition by the Chief Rainmaker. The accompanying sketch (No. 1) represents the rod used to draw the rain clouds in any desired direction. Sketch No. 2 represents the two-headed spear used by the Chief in attacking hostile rain clouds !

The Chief seizes the end of the rod and holding it above his head at arm's length at a slight angle and with the hook pointing in the direction of the rain cloud he wishes to attract, he is supposed to draw the cloud towards him by working his arm up and down. When attacking a hostile cloud, the Chief seizes the rod (Sketch No. 2) in much the same manner as that adopted by natives in ordinary warfare. He then prances about gesticulating violently and giving 
vent in a loud voice to some strange words, fights the troublesome rain cloud! In the immediate vicinity of the Chief's village there are several fair-sized trees, with one end of ropes (made from wild creepers) fastened to some of their lower branches, and the other end pinned to the ground by small wooden pegs. When rain is required (and provided the appearance of the sky favours an almost immediate down-
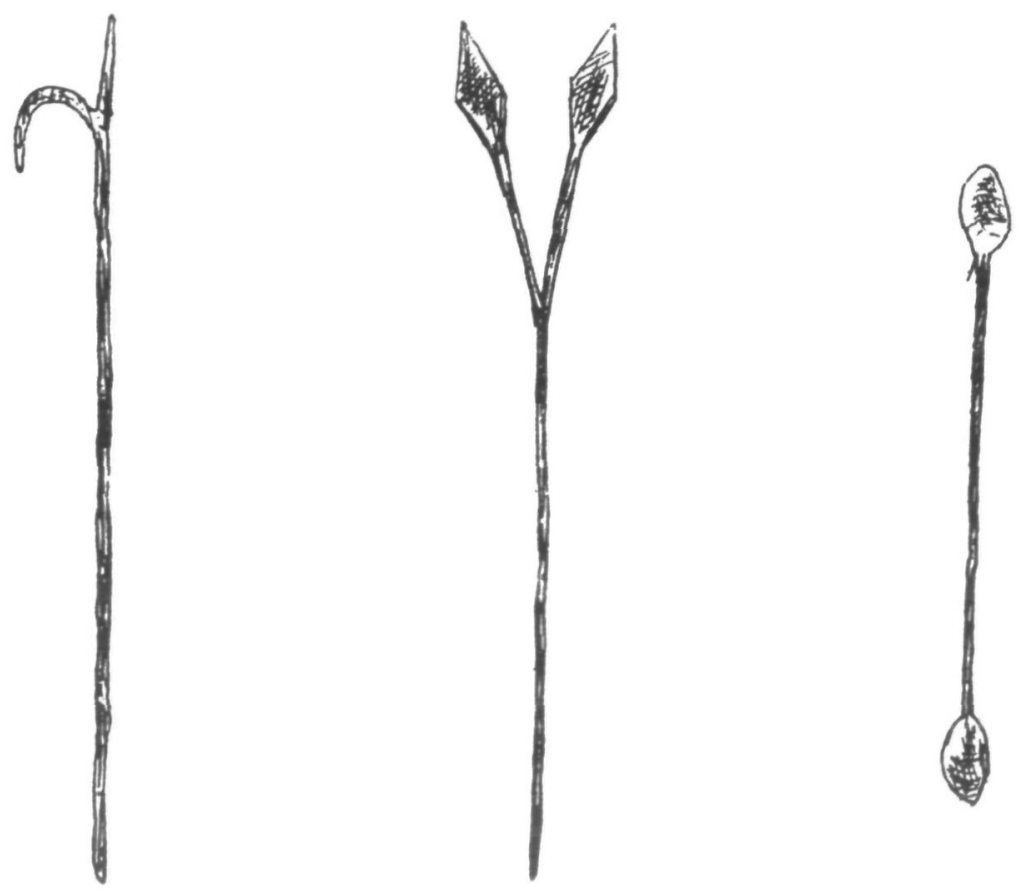

$N=1$

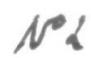

$1 \div 3$

pour; and there is consequently no time for the stone oiling process) the rainmakers proceed to one or more of these trees and pull at the ropes, so causing the branches to sway in the direction they wish the rain to fall. Their wishes invariably coincide with the apparent course of the rain cloud. Applications for rain are only made in the wet season. The Natives have the greatest confidence in the 
rainmaker's powers at this season, but candidly admit their disbelief in him at any other time.

Previous to British occupation it was the custom of these Natives to kill or severely punish the rainmaker if he did not produce rain when requested in the proper season. I have myself, more than once, been solemnly asked by natives (who, judging by the intelligence they display in other matters, one would consider ought to know better), to arrest and put to death or severely punish So-and-So for stopping the rain! I remember an instance where a Bari Chief living on the west bank of the Nile and who in former times had held considerable sway over a large tract of country N.W. of Lado, came into my office with a polite note from the officer commanding Lado, explaining that bearer, the Chief referred to, wished to lay a complaint against a Bari Chief living at the foot of BeLINLAN Hills, about 8 miles S.E. of Gondokoro. The Belinian Chief was duly sent for and confronted with the gentleman from the west bank. It then transpired that some twenty-five years ago, the father or former Chief of Belinian married a daughter of the western gentleman. After some years of happiness, the couple quarrelled and the lady returned to her father's home, the husband demanding from the father the return of the dower paid for her. After years of argument, a portion of the dower, consisting of goats, sheep, hoes and spears, was returned by the father to the husband with a promise to pay off the balance at some subsequent date. That balance had never been paid. The husband died some years ago and his representative, the present Chief of Belinian, had made repeated applications for the payment of this balance, but the old man from the west bank had explained that he was now very poor, and quite unable to pay the sum demanded. In consequence, this Belinian Chief, who has the reputation of being able to make rain, refused to give him any, and he now begged me to intercede on his behalf and compel the Belinian Chief to supply him with rain. I utterly failed to convince the old man that the Belinian Chief had no more control over the rain than he or I had. He drew my attention to the fact that there had been rain at Belinian every 
day for the past week, while at his home N.W. of the Nile, about 30 miles from Belinian, there had been, in spite of many threatening skies, no actual fall for Io days. I admitted the accuracy of his statement and explained that the Belinian Chief probably got more rain because he lived near hills and that the rainfall was often greater in the vicinity of hills, and my advice that he should select the base of some neighbouring hill such as Lado, which was within easy reach of his home, for his cornfields, was sorrowfully declined.

Amongst the tribes inhabiting this part of Africa there are numerous rainmakers but Ledju is generally admitted to be the chief among the Bari tribe, or at any rate that portion of it inhabiting the Bari country from its southern boundary the UMa River to about $5^{\circ} \mathrm{N}$. Latitude. Ledju's reputation as a rainmaker is no doubt largely due to the elevation and configuration of the country inhabited by him, his village, which is quite close to the site of his late father's, being situated, as already stated, on a small hill and considerably above the surrounding country, in close proximity to some still higher rocky, timber-clad heights. Ledju confessed to me that neither he nor any of his assistants really believed they were able to make rain, but their fathers before them were supposed to possess such powers, and the inhabitants consequently believed them to be possessed of the same. What therefore were they to do?

Some time ago Ledju publicly announced his inability to make rain and in consequence the population seriously threatened his life, and he was obliged to fly to the Government Station for protection, where he resided for some time. Before leaving the vicinity of the "nests," in reply to a question, Ledju informed me that I was the only white man who had ever seen his rainmaking implements and that strangers, including blacks, were not permitted to view the implements, but I being his "father" he had made an exception in my case. ( $I$ was also presented with a small selection of stones from the nests.) Ledju added that I must however allow him to make "medicine" for my eyes after witnessing such a wonderful sight ! On my consenting to this arrangement, I was requested to stand in front of the 
Chief with closed eyes. I accordingly, to all appearances, obeyed. The Chief waved his open hands in front of my eyes at the same time muttering in a low voice some strange-sounding words, then assured me that all was well. I was able to watch his movements as I did not quite close my eyes. I.edju is also supposed to possess other extraordinary powers besides those of a rainmaker. He showed me an iron rod (Sketch 3) about 3 feet long and about $I$ inch in diameter with a kind of hollow iron bulb at each end and containing bits of stone. This particular implement is used to induce women to bring forth large families, the modus operandi being for the husband to bring the would-be mother to Ledju, who, grasping the iron rod in the centre with the right hand, shakes it over and around the woman, rattling the stones in the bulbs at the ends of the rod, at the same time muttering some strange incantation.

F. SPIRE. 